the Yuen $\mathrm{Fu}$ are very fine, presenting a succession of bold outlines and rocky peaks. A dark-gray quartz-felsite was obtained from a high peak in a range of hills bounding the water-shed of the Min on the south. From the base of the hills a stretch of low flat reclaimed land extends to the coast. The soil of the hills is of a bright red colour, contrasting with the dark tints of the felsitic rocks.

The fourth group of stations includes a number of localities around Hai-tan Strait. Here the hills present vivid colouring, which contrasts very markedly with the white sands of the shore, especially on Hai-tan Island itself. This consists of three ranges of hills, with intermediate barren plains. Near the north point is a group of reddish sand-cliffs, from 20 to 30 feet high, horizontally stratified, and presenting flat summits, which form a miniature plateau deeply trenched by numerous gullies. At the mouth of the strait is a small barren island-Tessara I-land -composed of gneissose rocks, which carry iron pyrites. Slut Island, about 400 feet high, yielded a dark porphyritic feIsite, and a weathered surface of the rock displayed evidence of fluxion structure. Syang Point, at Hai-tan, shows granitic rocks running up into high hills. Kiang-shan, on Hai-tan Island, is a hill 1800 feet high, composed of dark-gray quartz-felsite. Mount Bernie, on the mainland, at the south end of the strait, about $\mathbf{1} 400$ feet in height, is composed of a similar rock, weathering to a reddish earth; and in Hungwah Sound the hills are of similar character. In Ockseu, a small rocky island, about twenty miles south of Hai-tan, is a dark-coloured rock, apparently dioritic, and certain masses of this rock when struck, emit a ringing sound, like that of a phonolite. There are here numerous veins of quartz, some showing rather bold crystals, and a good deal of schorl, or black tourmaline. It is notable that the island of Ockseu is especially subject to seismic disturbances.

\section{THE METEOROLOGY OF INDIA}

$I^{T}$ is perhaps inseparable from the mode of issue of the "Indian Meteorological Memoirs" that their titles (e.g. Vol. III. Part I., I.-Rainfall, Part I.) are rather complex. It is stated that this memoir is to be in three parts, whereof the present part treats only of the normal rainfall of India; Part II. is to treat of its variations in past years; Part III. is to contain the tabular data : the whole to form Vol. III. of the series.

As India depends chiefly on agriculture, the investigation of the conditions affecting its rainfall is of the highest practical import ance to it. The registers of rainfall available are, except a few private ones, all official work done under Government orders. Some few extend from I 844 , but the most of those accepted as trustworthy, after a critical examination, date from about IS62 the discussion includes the data only down to 1883 , i.e. covers pretty nearly a complete record for twenty-two years. Altogether, the registers of 424 stations are reviewed : for purposes of discussion these are grouped into twenty-five "rainfall districts," i.e. districts with similar rainfall.

From all these it appears that the average rainfall of the whole of India, excluding Burmah and the Himalya, is about 42 inches. The range of rainfall over this wide area is one of the most wonderful in the world, viz. from about 500 or 600 inches in Cherra Púnjí to from $I$ to 5 inches in Sindh. The average annual range over the whole of India (as above) is about 13 in the whole 42 inches. The rainfall is discussed under four heads :-

(I) Summer Monsoons.

(3) Winter Rains.

(2) Autumn Rains in South-East.

The local distribution of $\mathrm{I}, 3$, and 4 is well shown by tints of various shades on three maps. For the connection with the state of air-pressure, twelve maps are given, showing the isobars for the mean pressure of each month; the discussion of this connection is c implicated, and difficult to summarise.

(I) Summer (South-West) Monsoon.--By some, the south-west monsoon is considered to be an extension of the south-east tradewinds, but the author considers their connection to be very

1 "Indian Meteorological Memoirs," Vol. IrI., Part I. I.-The Rainfall of India, Part I. P. I16, and 9 Plates. A Monograph by H. F. Blanford, F.R.S. (Calcutta: Government Printing Press, $x 886$.)

"Indian Meteorological Memoirs," Vol. IV., Part I. Pp. 57 , and 4
Plates. Edited by H. F. Blanford, F.R.S." (Calcutta : Government Printing Press, r886.)

"Report on the Meteorology of India in $888_{4}$, " by H. F. Blanford, F.K.S. Pp. 305 and 3 Plates. (Calcutta : Government Printing Press, 1886$. doubtful, and gives a rough calculation, showing that the evaporation from the Northern Indian Ocean, land of India, and Bay of Bengal is enough to account for the whole of this season's rain. This rainfall is far the heaviest of the four seasons, and the most important for agriculture for most part of India, being, in fact, popularly styled "the rains." On its sufficiency depend the lives of millions. The distribution is at once seen by the tinted map. The west coasts of India and Arakhan catch the first and heaviest fall of over 100 inches : this does not top the coast range of mountains. The next heaviest is from the head of the Bay of Bengal to the Himálya, thence all along the lower Himálya, of from 50 to 70 inches. The amount decreases thence steadily with distance from the head of the Bay of Bengal, and from the Himálya, dwindling to almost nothing on the south-east const and north-west border.

The effect of a mountain-range in intercepting rain is clearly brought out, e.g. in the Western Gháts this rainfall, coming from the south-west, decreases from 250 inches on the coast to 40 inches at 30 miles inland, and to 20 inches at 60 miles from the coast. Again, very little rain crosses the outer snowy range of the Himálya. In fact, it seems to be an established law that the precipitation of rain from damp air is greatest in an ascending current from the chill produced in the ascent, and only moderate in a horizontal current.

(2) Autumn Rains in South-East.- The author shows that these are not (as often stated) a part of the north-east monsoon, but are, in fact, a late part of the south-west monsoon, corresponding to the late and heaviest part of the same on the Arakhan coast.

(3) Winter Rains. - These are popularly styled the north-east monsoon, and are popularly said to be due to a reversal of the conditions of the south-west monsoon. Their distribution is, roughly speaking, the opposite of that of the south-west monsoon, and is well shown on the map given. The south-east coasts, which scarcely feel the south-west monsoon, catch the maximum of over ro inches of this season, the North-West Himálya catch from 5 to Io inches, the head of the Bay of Bengal from 3 to 5 inches, and the rest of the country less and less with increased distance from these places.

Small as these quantities are (compared to those of the southwest monsoon), they are of the greatest importance to some of the localities named, especially to North-West India, as on them depends the growth of the valuable crops of temperate climates, e.g. wheat, the staple of North-West India; indeed, in the extreme north-west the winter is the dampest season.

(4) Spring Storms. - This rainfall is distinguished by increasing with the advance of the season, i.e. with the rising temperature, and mainly restricted to the south and east provinces. It is often accompanied by hail and thunderstorms, and is common in the evenings. This rain is usually very local, of short duration, heavy, and frequently repeated.

Altogether, this is a most elaborate and valuable monograph on its subject-the normal rainfall of India.

Part I. of Vol, IV. of "Indian Meteorological Memoirs" contains three memoirs, each a short monograph on its own subject, by different authors : these will be dealt with separately.

1.-_" Account of the South-West Monsoon Storm of May 12-1 7 in the Bay of Bengal and at Akyab," by J. Eliot (pp. 38, and 2 plates). The history of this storm has been worked out from the meteorological reports of fourteen coast stations, and the logs of fourteen ves-els passing through the Bay of Bengal The states of the barometer and wind are shown for four days on four charts, and the track of the storm-centre on another. The meteorological conditions seem to have been remarkably uniform over the Bay of Bengal for a fortnight preceding the storm ; indeed, this seems to be the normal state of things before a cyclone. The south-east trade-winds seem to have extended north of the equator on May Io and I I, and gradually advanced into the Bay of Bengal, as strong south and south-west squalls, with rain, increasing in violence within the Bay. In front of these, a barometric depression was formed about the $\mathrm{I}$ ath, round which, as a vortex, the wind became cyclonic. This cyclone advanced in a curved path north and east (whereas most cyclones advance north and west up the Bay), increasing from 6 miles per hour on the $15^{\text {th }}$ to 15 miles per hour on the 17 th, and broke up on the Arakhan Hills close over Akyab on the 17th, doing great damage to property

II.-. "On the Diurnal Variation of the Rainfall at Calcutta," by H. F. Blanford, F.R.S. (pp. 8, and I plate). This is a 
discussion of the hourly frequency and quantity of rain in a period of seven years (1878-84), derived from a self-registering Casella's hyetograph. The results do not seem of much practical importance. In the rainy season the rain is least frequent at the hour of maximum pressure, and most frequent at the coldest hour. At other seasons, dust-storms, with rain, are commonest in the evening. The greatest and least rainfall occur in general at the hours of greatest and least frequency.

III. - "The Meteorological Features of the Southern Part of the Bay of Bengal," by W. L. Dallas (pp. 11, and 1 plate). This is a discussion of the meteorology of a square district of $4^{\circ}$ by $4^{\circ}$ of the Indian Ocean, about half way between Ceylon and Sumatra, derived from the logs of ships. The air-pressure is at a maximum in January and at a minimum in May, with slight minima in July and October, which seem related to the occurrence of cyclones. The diurnal variation is extremely regular, the minima falling about $3 \mathrm{~h}$. $3 \mathrm{Om}$. and $\mathrm{I} 5 \mathrm{~h} 40 \mathrm{~m}$., and the maxima about $9 \mathrm{~h}$. and $22 \mathrm{~h}$. The range is markedly largest in April and September, i.e. at the two great seasonal changes. The mean temperature is $80^{\circ} \%$, and the range of the mean monthly temperature is only $3^{\circ}$, which is smaller than at any coast station: the diurnal range of the year is about $2^{\circ} \cdot 7$, varying from $3^{\circ} \cdot 75$ in April to $\mathbf{r}^{\circ .8}$ in May, the maximum and minimum being thus close together. In the summer (south-west) monsoon calms are rare. From April to September the wind is pretty steady from south-west to west-south-west, and, from December to March, generally from north to north-east. Only thirteen gales are recorded in twenty-five years, and none of them over force 9 of the Beaufort scale.

Mr. Blanford's "Report "for 1884 is a discussion of the meteorology of India in 1884 , on the same general plan as adopted for the ten years preceding. The discussion rests on observations supplied from 134 reporting-stations. Each meteorological element is discussed separately, beginning with the solar radiation as being the prime cause of all meteorological change ; next, earthradiation, temperature, humidity, cloudiness; and, lastly, rainfall. The great extent of India, and its isolation by ocean and mountain from other countries, render it a country most favourable for meteorological study. One singular feature is, that most considerable variations are of a somewhat lasting character, sometimes lasting two seasons, e.g. heavy snow in the spring in the Himálya is followed by steady north-west winds over the plains of Northern India, afterwards turning into the hot west winds.

The year under review was in some ways peculiar. Perhaps the most striking feature brought out is that, ever since 1878 , the temperature of insolation and of the air have both steadily fallen, and were lowest in $1884\left(1^{\circ} \cdot 2\right.$ less than in 1878$)$, although the sky was slightly less cloudy than in 1883 : it seems likely that this is part of a cyclic change connected with that of the sunspots, the temperature being highest at the sunspot minimum, and vice versá. The mean air-pressure was slightly $\left(\mathrm{o}^{\prime \prime} \cdot \mathrm{or}\right)$ above that of past years, and also much steadier. The average humidity was rather lower, and the average clearness of sky somewhat greater than in the recent years, and yet the total rainfall was somewhat greater : this was chiefly due to excess of rain in North-West, Central, and South-East India. Heavy snow fell in the North-West Himálya early in the year, bring ing rain to the North-West Punjab, and dry north-west winds in North India generally, followed by a hotter summer than usual. The south-west monsoon bringing the rain sets in in North India in June. The storms of the year were somewhat singular. From July to September a series of cyclones formed in the Bay of Bengal, and followed a north and west course far into the plains of India: this course seems to be the usual cyclone track of the Bay of Bengal. One of these, in July, crossed the entire breadth of India, and one, in September, lasted over a fortnight. Heavy snow fell in the outer Himálya in September and October, followed by north-west winds in North India, and by an unusually cool winter in India generally. Twelve charts accompany this Report, showing the mean monthly temperature, air-pressure, and wind; the isotherms, isobars, and wind-resultants being plotted in colours on each monthly chart. This annual Report, of which a very brief summary only is here given, is the outcome of an enormous amount of labour: the detailed tables of data covering 305 quarto pages, these tables being themselves mostly the result of laborious computation from the data furnished by the observatories.

\section{UNIVERSITY AND EDUCATIONAL} INTELLIGENCE.

CAmbridge. - The Mathematical Examiners have bracketed as Senior Wranglers Messrs. Baker and Flux of St. John's, and Iles and Michell of Trinity. It is unprecedented to have a bracketed Senior Wrangler. No women students have this year been placed as Wranglers.

The following women students have been placed in the first class of the Natural Sciences Tripos, Part I,, E. E. Field, A. J. Flavell, and M. M. Smith, all of Newnham College.

The Honorary Degree of Doctor in Science has been conferred on Prof. Asa Gray, of Harvard.

\section{SCIENTIFIC SERIALS.}

Annalen der Physik und Chemie, No. 6, June.-R. Emden, on the vapour-pressures of saline solutions. Criticism of prior results, and fresh experiments conducted according to the method of Konowalow. Babo's law, that the vapour-tension of saline solutions is always proportional to that of pure water at the same temperature, is shown to be true between $20^{\circ} \mathrm{C}$. and $95^{\circ}$ C. - Max Planck, on the principle of increase of entropy. Application of this principle in the study of dissociation of gases.-C. R. Schulze, on the amount of water of crystallization held in various salts. Proves the existence of a new form of sulphate of magnesia having density $\mathrm{I} \cdot 898 \mathrm{I}$, containing six molecules of water, and therefore differing from Mitscherlich's salt of same composition of density $1 \cdot 615 \mathrm{r}$. -W. Voigt, on the theory of light for absorbing isotropic media. A development of the theory propounded by the author three years ago. $-\mathrm{C}$. L. Weber, on the galvanic conductivity of amalgams. The amalgams examined were of tin, bismuth, lead, cadmium. Addition of tin increases conductivity of mercury; bismuth increases it until ro per cent. of bismuth has been added, after which further addition decreases the conductivity ; lead shows a maximum at about 25 per cent. ; cadmium produces a steady increase in conductivity. - Adolf Koepsel, determination of magnetic moments and absolute strength of currents by means of the balance. The method is due to R. von Helmholtz, and is independent of the earth's magnetic field or its variations. The author has made by this method a new determination of the electro-chemical equivalent of silver, which he gives as $0.017740 \pm 0.0000022$ in C.G.S. measure. Lord Rayleigh's value was 0.011794.- Walter König, magnetic researches on crystals. A very careful research on magnetic susceptibility of quartz and calc-spar in magnetic fields of various degrees of intensity. The two principal permeabilities in calc-spar possess a constant difference in fields of various strengths up to 3000 C.G.S.; for quartz, the difference diminishes as the field is strengthened, and is less than that of calc-spar.-R. Clausius, reply to some remarks of Lorberg upon dynamo-electric machines.-A. Foeppl, electricity as an elastic fluid. A speculative paper: the author thinks the existence of the Hall effect a criterion of his theory. $-K$. Wesondonck, on the absence of polar difference in spark-potential.-G. Meyer, note on the index of refraction of ice; the value for sodium light is $1 \cdot 3133 .-\mathrm{E}$. Ketteler, on the dispersion of rock-salt. The author thinks he has established the law that the absorbing power of substances for heat-rays is proportional to the negative coefficient of the term in $\lambda^{2}$ in the formula which he uses in place of Cauchy's for the law of dispersion.-W. Voigt, reply to Wernicke's remarks on elliptic polarization.-F. Braun, on the diminution of the compressibility of solutions of sal-ammoniac with increase in temperature.-A. Overbeck, on the signification of the absolute system of measurement.

\section{SOCIETIES AND ACADEMIES.} LONDON

Geological Society, May 25.-Prof. J. W. Judd, F.R.S. President, in the chair.-The following communications were read:-On the remains of fishes from the Keuper of Warwick and Nottingham, by Mr. E. T. Newton; with notes on their mode of occurrence by the Rev. P. B. Brodie and Mr. E. Wilson.-Considerations on the date, duration, and conditions of the Glacial period with reference to the antiquity of man, by Prof. Joseph Prestwich. After showing how the discoveries in the valley of the Somme and elsewhere, twenty. eight years ago, led geologists who had previously been dis. posed to restrict the age of man to exaggerate the period during which the human race had existed, the author proceeded to 